\title{
GLOBALIZATION PROCESS IN THE MARITIME TRANSPORT - CAUSES, SYMPTOMS AND EFFECTS
}

\author{
Aneta Oniszczuk-Jastrząbek ${ }^{1}$ \\ Ernest Czermański ${ }^{2}$ \\ Olga Dębicka ${ }^{3}$ \\ Tomasz Czuba ${ }^{4}$
}

\begin{abstract}
Globalization poses new challenges and creates development opportunities for strong and dynamic companies and new branches that shape markets and the economy in the global dimension. This process has a major impact both on the economies of countries, particular branches of economic activity, as well as on economic entities operating in maritime transport. Despite various activities in individual countries of the world, globalization affects the functioning of virtually all enterprises regardless of their size and form of business. This process forces enterprises to take active measures to, on the one hand, "defend" their own market from competition, and the other to seek new, attractive markets for their goods and services. The economic activities undertaken in every country of the world depend on many factors. Although the globalization process makes these factors similar, still their impact seems to be quite diverse. The dynamics of observed changes in the economy is also different.

The aim of the article is to present a reflection on the strength of changes in the global economy at the global level and an attempt to show the interdependence between economic globalization and the development of maritime shipping. To this end, two directions were delineated in the considerations. The first one, indicating the importance of globalization in the development of maritime shipping and the second one, indicating the share of developing intermodal technologies in expanding and developing globalization processes in the global economy. Such a division results from the nature of both these phenomena and their mutual correlation, as the interdependence between all phenomena that take place in the global economy is obvious. Therefore, according to the theory of economics, one should not prove whether the phenomena are related to each other, but how, how strong are the connections and on which levels they occur.
\end{abstract}

Key words: globalization, transport, maritime shipping

JEL code: F6, L91, L99

\section{Introduction}

From its beginning, globalization has been seen as a positive process. The international organizations, such as the General Agreement on Tariffs and Trade (GATT), the European Economic Community (EEC), the European Free Trade Association (EFTA), and the Organization for Economic Cooperation and Development (OECD), were then established to promote the development of the globalization process. One of their goal was to facilitate international trade by removing or reducing customs barriers. In a wide range, these activities have contributed, and are still contributing, to increasing trade between enterprises, making them more competitive on the

\footnotetext{
${ }^{1}$ Gdańsk University, Poland, e-mail: ekoao@ug.edu.pl

${ }^{2}$ Gdańsk University, Poland, e-mail: e.czermanski@gmail.com

${ }^{3}$ Gdańsk University, Poland, e-mail: olga.debicka@gmail.com

${ }^{4}$ Gdańsk University, Poland, e-mail: t.czuba@ug.edu.pl

DOI: 10.29302/oeconomica.2019.21.1.7
} 
market through access to modern technologies and effective management methods. While discussing other advantages of the globalization process, it is worth mentioning the increasing value of foreign direct investment in individual countries. FDI became the engine of globalization processes and influenced either directly faster economic growth in these countries, and contributed indirectly to improvement of living standards, growth of enterprises' innovativeness and enabled them to expand internationally.

\section{The concept and determinants of the globalization process}

In recent years, a term globalization has become very popular, entering permanently into both colloquial and professional language. Globalization can be discussed as a process of enterprise expansion into foreign markets [Yip, 2004], due to the elimination of entry barriers between countries. The concept of globalization can also be related to market phenomena consisting in "(...) treating the world as a single market" [Rymarczyk, 1996] or to all global economic processes that have certain characteristics of holistic behaviors [World Economy, 1991]. According to A. McGrew, the concept of globalization consists in increase of connections between various international entities and mutual interactions in all spheres of social life [McGew, 1992]. In the literature on the subject we can find a definition in which globalization is treated as "connections and interactions between individual states and their societies, in horizontal and vertical dimensions, which ultimately leads to the creation of a homogenous world system" [Flejterski, Wahl, 2003]. According to K. Kuciński, globalization means "(...) the global process of integration of economic systems and business entities. It consists in the fact that economic activity is set up and coordinated on a global scale in order to minimize costs, maximize the newly created value of products and gain access to the global market" [Kuciński, 2002]. While discussing the definition of the globalization process only in economic sense, the most accurate one can be the definition developed by A. Zorska, who stated: "(...) globalization of economic activity is a worldwide long-term process of integrating a growing number of national economies above their borders, thanks to the expansion and intensification of mutual ties (investment, production, trade, cooperation), as a result of which a worldwide economic system is developed - a system of high interdependencies and significant repercussions for activities undertaken / even in distant countries" [Zorska, 1998]. Due to the diversity of definitions, in this article the concept of globalization is treated "(...) as a process of deepening integration of national economies, manifested in the dynamic growth of trade, international capital and service flows, resulting from the growing tendency to treat the world as a common market by growing number of enterprises" [Piklikiewicz, 2000].

Thus, the globalization manifests in dissemination of the free market principles and the elimination of territorial, political and national restrictions for economic activity. As M. Rosińska wrote: "(...), although globalization concerns the macroeconomic sphere, it is a phenomenon that forces changes mainly at the microeconomic level - that is in the enterprises' strategies. It boils down to increase in the pace of implementation of new solutions and the dissemination of improved products and services, to shortened product life cycle, thus exacerbating the competitive struggle between enterprises. The measure of success in new conditions is, therefore, the speed of perceiving changes in the environment, the ability to flexible adaptation to them, ie the ability to create innovative solutions that respond to current market challenges" [Rosińska, 2006].

Globalization is a process that affects the enterprises activities, especially the competition on the market, through [Stankiewicz, 2002]:

- development of market economy,

- progressing deregulation of the economy,

- opening to global markets, 
- reduction of restrictions on international flows of goods and services,

- growing capital flow (including people),

- development of financial markets and the financial products,

- government incentives for foreign investors (increase in foreign direct investment),

- keeping international standards of cooperation and product quality,

- harmonization of consumption patterns and lifestyles,

- development and spread of modern production technologies as well as telecommunications and IT technologies,

- fast and less-restricted flow of information,

- development of communication, transport, management methods and supporting them IT systems,

- concentration of capital on a global scale,

- increasing the importance of using standardized quality management procedures (certificates) and environmental protection requirements.

C Szulczyński formulates three following concussions addressed to the enterprises precisely [Przedsiębiorstwo ... Value ... 2007]:

- "through globalization a new quality of market mechanism is developed, which creates a wider, even civilizational challenge for an ever larger group of its participants, and thus places them at a level and intensity that they have not experienced before,

- meeting these challenges (allocation of resources, distribution of effects) leads to farreaching changes in the basis for the setting-up (subjectivity) and functioning of enterprises and the assessment of the results of their operations,

- among the most important factors of this enterprises functioning and assessment are included criteria and values which are widely and even globally accepted (eg value for the client, value for the shareholder)".

The impact of globalization on the economy may result from the following forces leading to globalization: technological, social, political and legal as well as economic (Figure 1).

These forces allow local enterprises to develop and then implement strategies that will help them achieve the goal of operating within an international and even global enterprise.

In each of the listed groups there are several factors that occur in the economies of many countries. For example, the group of technological forces includes industrial development, transport development and improvement of information flow. Industrial development is associated with changes taking place in the field of technology for many centuries. They were caused was by, inter alia, the industrial revolution, industrialization activities and development of a tendency to mass production of goods. Development of transport, both rail, sea, and, most importantly, air is of no less importance. This enables, on the one hand, the improvement of transport conditions for materials and goods on a global scale, and on the other hand, it leads to the opening of national markets to new products. A phenomenon of improved information management, also called information "revolution" is one of the technological achievements, and the widespread acquisition of information and its exchange through the global Internet network are among its major effects [Oniszczuk-Jastrząbek, Gutowski, 2008]. 


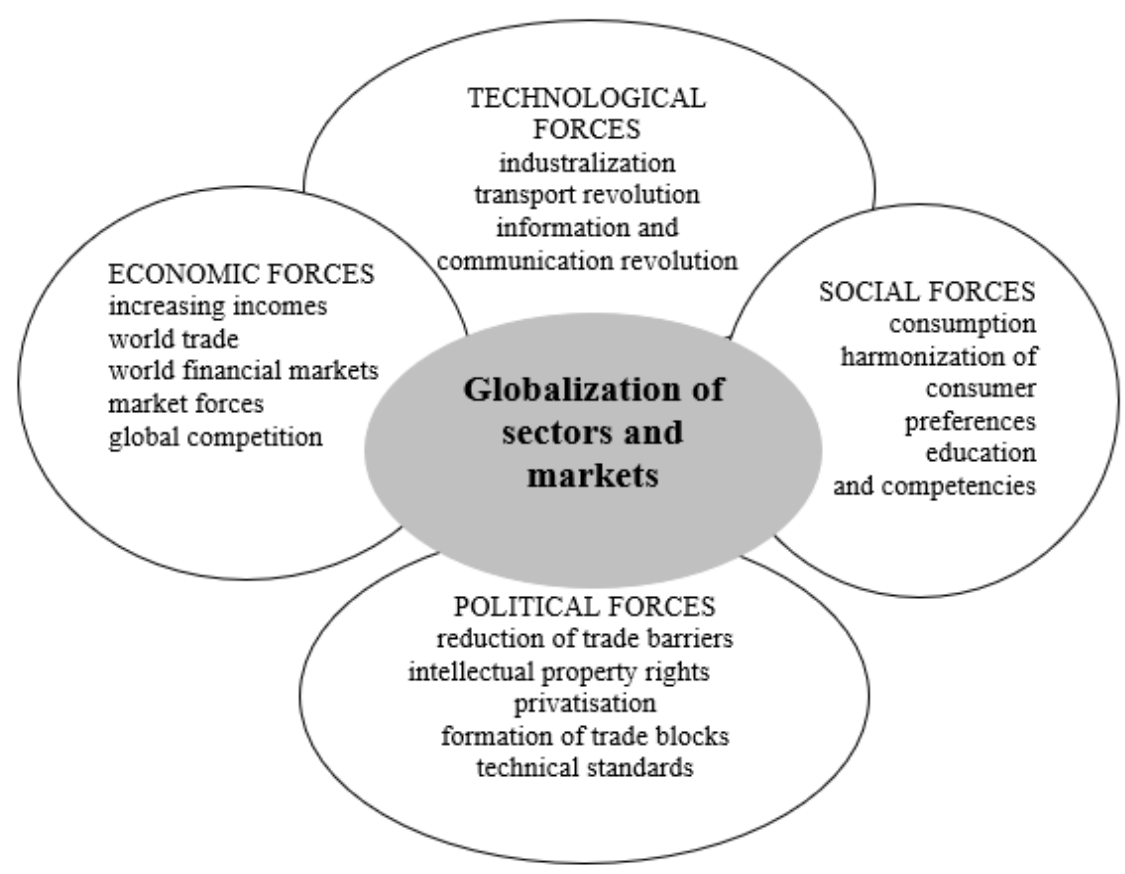

Fig. 1. The forces leading to globalization

Source: G. Stonehouse, J. Hamill, D. Campbell, T. Purdie, 2001. Globalizacja. Strategia i zarzadzanie, Warszawa, Wydawnictwo Felberg SJA, p. 25.

Social forces have an important impact on changes in national economies. They can result in, inter alia, the increasing level of income of the society or increase of individual demand. These factors lead, as a consequence, to the emergence of global consumption, which is driven also by the growing exchange of goods and services between countries. The reason for this is the reduction of trade barriers, which are included in the next group of forces leading to the development of the globalization process - political and legal forces. Among other factors are growing legal significance of intellectual property rights in some countries, which plays an important role in the protection of global products and brands. It should also be stated that the globalization process would not be possible without economic forces affecting this phenomenon. The essence of their impact is mostly connected with the increase of global competition.

\section{Globalization process in maritime shipping - reason for development}

One of the first reason of the globalization process in maritime shipping is the progress of technology in transport and transshipment, including in that containerization or, more generally, the phenomenon of the cargo unitization in transport. The last factor played a particularly important role in maritime transport, which was dominated by containerized cargoes. For the needs of the present analysis, it should only be emphasized that the unitization of cargo in trade (supported by ISO in the technical aspect of this exchange), has simply the transport process on a global scale. Standardized ISO containers, identical all over the world in their several basic types and dimensions, can be handle by most of the enterprises in TSL industry in the world, both in transport and transshipment processes. What's more, the strong development of containerization has resulted in the specialization of some transport companies and the emergence of a new market segment container transportation and handling. Development of this process resulted in emergence of container operators in maritime shipping who specialized in container transportation. Moreover, special port and land container terminals have been built to handle only containerized cargoes.

Another reason of globalization process is the wide application of IT in the planning and control of the delivery process - common in every area of business operation, also in storing and reloading. Such processes are supported nowadays by bar codes, computer systems and satellite 
monitoring, allowing for finding at any time the location of a specific container, either on the storage yard, in the hold or being in motion. In addition, IT plays a large role in integrating all participants of transport processes into one system and in one database. Its importance results from numerous specialist software for e.g. container terminal operators, forewarders, as well as in equipping each participant of the supply chain with a computer with access to the appropriate network. It is also worth mentioning the numerous projects carried out due to the European Union co-financing (e.g. within the Interreg program), such as the NeLoC, InLoC or BaSIM projects conducted by Polish partners. Their goals were generally to improve cargo flows by creating new or modifying existing software. The effects of this phenomenon, as well as the previously discussed one, have a direct impact on transport results in maritime shipping.

Liberalization and unification of trade and transport regulations is the third reason for globalization in maritime shipping. It refers mainly to the secondary effect of opening the state borders, which have been closed for political reasons. Initially, the economies of these countries were being opened to import of goods from abroad, but goods had to be delivered to the recipient somehow. Thus, one can speak about a secondary effect of the trade liberalization on the shipping sector - as a service accompanying this trade. Initially, the import of former socialist states was carried out with its own fleet but opening of this markets resulted in full access of foreign carriers and transport organizers to the domestic market. This phenomenon has also additional importance in maritime shipping by internationalization of standards and regulations (technical, legal) in container handling. We can therefore speak first about the economies opening up to new transport technologies, and then about adopting unified regulations and rules on the use of a container as a basic cargo unit in transport.

As in the previous case, a barrier of demand is a secondary phenomenon in maritime shipping. This results from a fact that a need for transportation of unitized cargo appears after opening of the boundaries for foreign cargo. However, a barrier of demand for consumer goods, mainly highly processed, and therefore the most susceptible to unitization, was above all a fundamental problem, and therefore creating also a barrier in delivering and acquisition of transport services handling these goods.

The development of a compatible network of links between trading partners and carriers is another reason for globalization. This is a factor directly conditioned by rapid development of technology, especially IT which has enabled the merger of individual business entities into one global network. In addition, IT sector continuously provide newest and optimal operating systems for groups of companies that closely cooperate with each other, or for international consortia with foreign branches and representative offices abroad. Thus, IT delivers tools which enables direct contacts with contractors, bypassing the existing ways of communication. Thanks to this, it was possible to strengthen and significantly accelerate cooperation. Direct and immediate communication contributed to shortening the time of making an order or settlement process itself, which in turn accelerated the entire production process of goods and their transportation. The whole of these possibilities and events has led to the creation of a network of connections between shippers and operators who participate in the supply planning and logistics.

The sixth reason of the discussed process is a new civilizational structure. This factor is related to the direction of society development leading to new, higher level of consumption consciousness and expectations. However, this applies not only to rising demand of people, who become aware of variety of offered goods and services, previously not existing on the market due to demand barrier, but also to entrepreneurs, including carriers and forwarders. These companies, seeing new possibilities of earning, through the organization of supply chains, strive to take on the role of a transport operator. In this way, the structure of the transport services market was established, in which the transport operators who offer a complex door-to-door delivery with various accompanying services, start to play a dominant position. 


\section{Globalization process in maritime shipping - examples and symptoms} shipping:

The following phenomena can be listed among globalization symptoms in the maritime

- The importance of knowledge and management in organizing and delivering transport services. This factor concerns the implementation of integrated supply chain projects. A characteristic feature of the present times is not the lack of information, but their excess, so the ability to quickly match respective sources of data with current needs become valuable. Moreover, the ability to process and use information, is even more important. Hence, a great importance is given to a man who processes external and internal data, linking them in streams of information and making decisions based on them.

- Transnational corporations and megaconcentration of capital in enterprises, which is visible in the entire supply chain. The capital concentration, as a basic method of increasing enterprise competitiveness, transforms a market system by significant reduction in number of enterprises offering their services, while the total volume of service supply in a given sector does not decrease. For example, many seaports handed over container handling services to several international operators (TTOs - transnational terminal operators). At the same time, international shipping lines have expanded their services by operations at terminals, concluding contracts for long-term lease of specific berths for their ships. Thus, at the beginning of the 21 st century, international enterprises controlled over half of the world container handling market.

- A new specialization of nations in production and exchange. This phenomenon, unlike globalization, has different symptoms in the shipping sector. In transport and reloading of goods in international trade, according to what has been presented above, the national character of the majority of entities in this sector is blurred. In practice, only the largest international corporations are important. The transport market shows different trends in this respect than the production market. However, this does not mean that maritime container shipping is not of global nature. This character is even more evident due to the internationalization of entities operating in this market. In addition, this phenomenon can be further characterized as follows: along with the specialization of some nations in mass production on a global scale, e.g. China, India, USA, transport service handling these countries' exports is being developed at the same time. Therefore, on one hand, we can talk about keeping transport gestion in these countries through using their own enterprises, and on the other hand about the geographical extension of the supply market by enterprises in all countries of the world, capable and willing to handle this export.

- Development of business infrastructure. Efficient organization and implementation of integrated supply chains, which currently dominate in the general cargo trade, depends primarily on efficient tools used by the operator. Such operator has at his disposal reliable and increasingly improved handling equipment, modern land and sea terminals, but it is the development of telecommunications and IT that had the strongest influence on the acceleration of development in this sector. These two sectors of technical sciences provide managers and operators with tools necessary for company's organization and management. Such solutions as modern telecommunications platforms, modules integrating various telecommunications systems, and finally software supporting these platforms and programs enabling communications among all participants of the delivery process, constitute a modern business infrastructure. Therefore, this infrastructure must be understood as not just physical 
equipment (telecommunications networks), but rather the right software that integrates individual systems of different enterprises into one.

- Further technological progress in transport and reloading manifested in newer, better and more efficient devices. As an example may serve road vehicles, which have radically lower fuel consumption as compared with their first models, much lower exhaust and noise emissions and lower weight; moreover they are becoming energy-efficient and increase their capacity in terms of tonne-kilometers. When it comes to technical changes in reloading equipment, significant development is visible in their parameters (increase in lifting capacity, lift height, overhang, working speeds) and in the handling technology of unitized loads, especially containers. Modern constructors of, e.g. gantry cranes used in port container terminals, are not only aiming at shortening the duration of the reloading cycle in the relation wharf - side - wharf (today approx. 30 seconds comparing with up to 2 minutes ten years ago), but also at increasing a unit loading capacity by, for example, using two or more trolleys on a crane boom at the same time, using double-sided ship service in a port, reloading two containers at once, or even connecting several to a dozen or so containers to a transhipment unit. An important postulate is also the lowest possible failure of devices.

- Further liberalization and centralization of decisions in world affairs. This phenomenon also occurs in globalization. While the beginnings of such liberalization in international relations have created a serious impulse for the development of this process, further liberalization is already treated as a manifestation of globalization. It is a self-propelled mechanism. The first impulses conditioned the process, which in the present shape enforces somehow its further progress. It is becoming obvious that every country is going to participate and take advantage of the opportunities that globalization brings, so as not to join the group of those who only lose as a result of isolation. This results in numerous initiatives and the popularity of many international institutions and organizations.

- Development of a global financial and freight market. When considering international nature of maritime transport - the main branch in land and maritime intermodal transport from the beginning of its existence, it's evident that this transport required broad access to the discussed market. Initially, the merchants used their own fleet, but as telecommunications progressed (telegraph and telephone) the transport sphere (available on demand) has been separated from the commercial sphere. However, the greatest development of the freight market took place at the end of the last century due to modern information and telecommunications technologies. It has become possible to conclude contracts, charter, book, submit forwarding orders etc. on-line, i.e. on websites. The pressure of time in economic activity has largely eliminated physical contact between partners, which has been replaced by electronic communication, using standardized forms, codes, etc. The same method is also mostly used in payments in foreign trade. This unlimited availability of enterprises via the Internet is a sign of the emergence of a global freight and financial market

\section{The effects of the globalization process in maritime shipping}

One of the effects of globalization in maritime shipping is a new competitiveness system and global competition. As a result of the phenomena mentioned above, in particular economic and political liberalization, thanks to modern technology, concentration of capital, and the emergence of TNC's and global markets, the essential effect for the shipping market consist in the change in the competitiveness of entities operating there. In this context, the term "global competition" fully reflects the market situation that has been developed over the last dozen years in the international 
economy. For the sector in question, this concept means not only seeking cargo for transport (and possibly for refurbishment services) all over the world, but also fighting for it with other companies from around the world. Global competition in maritime shipping also means a market model similar to oligopoly, and less frequently to monopoly.

It results from a limited number of operators (TNC) on the market and an ever smaller number of independent carriers or forwarders. The new arrangement looks as follows: the global intermodal transport market, with a large number of entities on the supply side and even more entities on the demand side (alike in a perfect competition) should be divided into different segments. This division results either from various transport relations, e.g. Western Europe - SouthEast Asia (geographical criterion), various cargo units being transported, e.g. transport in Ro-La technology from Munich to Milan (unit criterion), or various companies providing services, e.g. Kombiverkehr GmbH (entity criterion). In each of these segments, the number of participants of transaction is reduced. This limitation is caused by the obvious fact of specialization, or it results from the fact that no entity can exist and effectively operate in all transport relations. There are just too many of them. The largest TNCs are able to take over the main transport relationship. In practice, they are most interested in ocean container transports, where the largest financial flows occur, and therefore the greatest profits are possible. On the other hand, feeder transportation is served by smaller, single shipowners or small shipowners' allies (e.g. the container line Hamburg Szczecin is served only by BCL Ltd.). Another characteristic feature of this market refers to the fact that main competitors are not other operators but rather other transport branches of transport.

Unification of organization and management of the transport and transshipment process, which results directly from the capital concentration of carriers and operators, as previously discussed, is another result of globalization. Here, however, one should emphasize a significant tendency. In the transshipment part of the supply chain, we can observe moving away from previous port terminal management system, based on two alternative models: combining the management of the terminal and its operation by the owner (e.g. English ports), or transferring the operational sphere to a specialized operator (e.g. German, Dutch and French ports).

In both cases, the terminal played a local role and offered services to all shipping lines entering that terminal. The development of global enterprises is an example of horizontal integration, which allowed for the extension of the scope of activity. At the beginning, operations were limited, and development opportunities were enforced gradually. This expansion allowed for highly effective management and operation in new situations, what resulted in increased revenues. The discussed development is also the result of privatization and liberalization.

Terminal operators could enter new markets by taking over entire ports (Felixstowe in 1991) or most of the port's terminals (Rotterdam in 2001), or by creating a joint venture, for example with the city authorities (Shanghai, 1998). Another source of global terminal management refers to maritime shipping. Many shipping lines sought expansion opportunities in other sectors of the economy. Due to vertical integration, these lines have taken control over a greater number of links in the supply chain, including container terminals, getting in that way more effective control over door-to-door services on a global scale. For large carriers, the terminals were a particularly attractive sector, as they accounted for up to $50 \%$ of the total container transport costs

The main difference between carriers and terminal operators (TTO) lies in the fact that shipping lines seek to control the berths of ships, while TTOs try to control the handling equipment used by various carriers. The difference in the approach of shipping lines to terminal management is also more visible.

Several major companies have established special terminal units that are not directly related to the shipping sector. For example: P \& O Ports is an independent enterprise within the group owing large shipping lines. Recently, the largest shipowner - Maersk - has created a separate company for terminal management - the APM Terminals International B.V. AS some of its reloading devices serve different users, this company is classified as hybrid one. Some carriers have 
rented parking spaces to serve only their ships, such as Hanjin in Long Beach or Evergreen in Italian Taranto.

Another consequence of the globalization process consists in qualitative changes in enterprises, the power of knowledge. It should be emphasized that a modern enterprise is based on human capital, i.e. knowledge and skills of the managers and lower-level employees. This requirement is also extended to the sphere of shipping. It can be even stated that enormous knowledge, skills and experience are especially necessary in the maritime shipping. Knowledge in one transport branch mostly refers only to that particular branch while tasks of the intermodal operator are much larger and thus require cross-cutting knowledge on all modes of transport (their techniques, technology, economics, legal regulations, contracts, customs, etc.). By extending the transport process, the provision of a comprehensive service for the recipient (sender) increases the scope of responsibilities and tasks of the operators. Therefore, their proper organization and implementation requires more knowledge and skills than before. In addition, like every global enterprise, the operator is subjected to global pressure, global competition and like other companies struggling for keeping or improving their market position, intermodal operator must put the emphasis on the stuff development.

The fourth effect of globalization refers to the polarization of income and position. This phenomenon also occurs in maritime shipping, being directly related to economic liberalization and global competition. Along with organizational and financial concentration of companies in shipping sector, as has been discussed earlier, they become the dominant entities in this market, and, of course, other companies lose their position. It means that we can observe a polarization of the market position - strong operators become more and more stronger through mergers, alliances and other such activities, while small and medium enterprises are either absorbed by larger entities through acquisitions or lose their position on behalf of "big players". The second group of companies can only stay on the market when finding a niche one, such as feeder or specialized transport.

Restrictions on the sovereignty of individual states. This phenomenon does not occur directly in the maritime shipping sector. It can only be stated by analogy that common international regulations concerning selected aspects of maritime transport (such as the Convention on Multimodal International Transport, ISO Container Standards) have truly their source in the process of globalization, in particular the liberalization of the international economy. However this is the only evidence of the importance of this phenomenon in the development of shipping.

When discussing the effects of the globalization process, external costs should be mentioned. The problem of incurring by society the external costs generated by the transport sector has become fundamental at the end of the 20th and the beginning of the 21 st century. Further work and research will certainly concentrate on rational methods of their internalization. Therefore, what we can we can expect in the coming years is the implementation (for example by the European Union) of new regulations imposing new financial burdens on enterprises generating these costs. Thus, the external costs and, in general, environmental degradation, constitute the most serious prerequisite for the use of intermodal transport technologies. Therefore, with progressing process of external costs' internalization, these new technologies are expected to meet with greatest interest. In this context, the issue of external costs together with the problem of their internalization should have been examined in future within the theory of economy. The development of internationalization principles of these costs and their implementation into the international economy will, however, remain unresolved until the total external costs generated by the shipping sector exceed the total benefits of society resulting from not raising prices for goods and services based on transport. While on the one hand it seems to be justified to charge the companies with the costs of environmental losses caused by transport of goods, on the other hand, such burden will be ultimately transferred to final buyers, i.e. consumers. Thus, the idea of leveling the chances of all transport modes and their sustainable development will be somehow lost in this way. Higher costs 
of road carriers will affect the price of their services. However, until the prices of road transport services reach the same level as prices in environmentally friendly services, all goods carried in road transport will be purchased at a higher price. Therefore, the first period - the so-called price harmonization in transport - will only burden the consumers. The researches within the theory of economy, in particular the economics of intermodal transport, should investigate to what extent this will happen, what will be the financial dimension, and how it will affect the structure of the global economy. This new field of science should focus not so much on the functioning and financing of individual stages of transport but on the cost-effectiveness of the entire delivery process in its various variants.

\section{Conclusion}

In conclusion, it should be emphasized that there are many opportunities associated with globalization, but also many threats. Chances include more effective use of resources, freer flow of goods and services, capital and technology, and modern organization methods. On the other hand, the threats associated with globalization are related to growing gap between rich and poor countries, the dependence of economic processes taking place in one country from events taking place outside its borders, and the negative human impact on the environment.

\section{Biblography:}

1. Flejterski S., Wahl P., 2003. Ekonomia globalna - synteza, Warszawa, Difin, p. 18.

2. Gospodarka światowa, 1991. Red. P. Bożyka. Warszawa, p. 307.

3. Kuciński K., 2002. Nasza ziemia - Gospodarka globalna, Poznań, Wyd. Kurpisz, p. 13.

4. McGew A., 1992. Concertualizing Global Politics [w:] Global Politics. Cambrige, p. 28.

5. Oniszczuk-Jastrząbek A., Gutowski T., 2008. Funkcjonowanie polskich małych i średnich, przedsiębiorstw w gospodarce globalnej [w:] Instytucjonalne i rynkowe uwarunkowania rozwoju matych $i$ średnich przedsiębiorstw w Polsce. Red. E. Michalski, S. Piocha, Koszalin, p. 50.

6. Piklikiewicz M., 2007. Integracja kontynentu amerykańskiego jako przejaw procesów globalizacyjnych [w:] Przedsiębiorstwo. Wartość. Zarzadzanie. Red. C. Suszyński, Warszawa, PWE, p. 53.

7. Globalizacja w gospodarce światowej, 2000. Sopot, p. 292.

8. Rosińska M., 2006. Podstawowe założenia koncepcji konkurencyjności przedsiębiorstw w kontekście globalizacji, [w:] Integracja a globalizacja, Tom 2, Wrocław, p. 240.

9. Rymarczyk J., 1996. Internacjonalizacja przedsiębiorstwa, Warszawa, p. 12.

10. Stankiewicz M. J., 2002. Konkurencyjność przedsiębiorstwa. Budowanie konkurencyjności przedsiębiorstwa w warunkach globalizacji, Toruń, p. 66-67.

11. Stonehouse G., Hamill J., Campbell D., Purdie T., 2002. Globalizacja. Strategia i zarzadzanie, Warszawa, Wydawnictwo Felberg SJA, p. 25.

12. Yip G. S., 2004. Strategia globalna, Warszawa, p. 27.

13. Zorska A., 1998. Ku globalizacji? Przemiany $w$ korporacjach międzynarodowych $i$ w gospodarce światowej, Warszawa, PWN, p. 14. 